\title{
The effects of exercise on C-reactive protein, insulin, leptin and some cardiometabolic risk factors in Egyptian children with or without metabolic syndrome
}

\author{
Nashwa Nabil Kamal ${ }^{1 *}$ and Merhan Mamdouh Ragy ${ }^{2}$
}

\begin{abstract}
Background: The prevalence and magnitude of obesity in the children and the adolescents have increased dramatically in the developing countries over the last 20-30 years. The prevalence of metabolic syndrome (MS) in children is increasing. Aim: This study aimed to investigate the changes of C-reactive protein (CRP), leptin, insulin, and blood lipids before and after the exercise therapy in normal and obese children (with or without metabolic syndrome).

Methods: The study covered 49 normal children (control), 32 obese children without metabolic syndrome and 12 obese children with metabolic syndrome. We examined the influence of exercise (3 times/week) for 12 weeks on the levels of serum CRP, leptin, insulin, homeostatic model assessment insulin resistance (HOMA-IR), triglycerides (TG), total cholesterol (TC), low-density lipoprotein cholesterol (LDL-C), and high-density lipoprotein cholesterol (HDL-C) in all groups.

Results: There were significant correlations between HOMA-IR and the individual components of the metabolic syndrome. After 12 weeks of exercise, both of the obese children groups, with and without metabolic syndrome, showed reduced body weight, body mass index (BMI), and CRP level, and increased HDL-C level. The percentage of metabolic syndrome decreased from $12.9 \%$ before the exercise training to $7.5 \%$ after training. Also, there was a significant reduction in BMI (from 47.3 to 32.6\%), in systolic blood pressure (from 18.3 to 15.1\%) and in HDL-C level (from 18.3 to $9.7 \%$ ).
\end{abstract}

Conclusion: Overweight children have multiple risk factors associated with the metabolic syndrome. 12-week exercise may have a positive effect on reducing risk factors for the metabolic syndrome.

Keywords: Metabolic syndrome, Exercise, Children, Cardiometabolic risk factor, C-reactive protein and insulin

\section{Background}

Metabolic syndrome is a cluster of cardiovascular disease risk factors that include glucose intolerance, hypertension, elevated TG, low HDL-C, and obesity [1]. This clustering has been shown to occur not only in adults but also in adolescents [2]. Although the metabolic syndrome is particularly important in adults, the pathological processes and risk factors have been shown to begin during childhood [3].

\footnotetext{
* Correspondence: nashwakamal@yahoo.com

${ }^{1}$ Lecturer of public health, Public health department, Faculty of Medicine, Minia University, Minia, Egypt

Full list of author information is available at the end of the article
}

This syndrome continues to increase in both developed and developing countries, and has already become a major threat to the global public health [4].

The prevalence of the metabolic syndrome in the children and the adolescents is relatively low; about 4\% [5]. When compared to the adult population (24\%), except amongst the overweight and obese adolescents where the prevalence of the metabolic syndrome has been reported as high as $29 \%$ [6].

Obesity is strongly associated with elevated concentrations of circulating markers of inflammation, such as CRP [7]. Elevated plasma levels of CRP have been associated with an increased risk of coronary heart disease

\section{Biomed Central}

(c) 2012 Kamal and Ragy; licensee BioMed Central Ltd. This is an Open Access article distributed under the terms of the Creative Commons Attribution License (http://creativecommons.org/licenses/by/2.0), which permits unrestricted use distribution, and reproduction in any medium, provided the original work is properly cited. 
and type 2 diabetes [8]. Childhood CRP values predict adult CRP [9].

Leptin, a hormone secreted by adipose tissue, acts on the inhibiting food intake and stimulating energy expenditure [10]. Leptin increases in obesity, type 2 diabetes mellitus, hypertension and metabolic syndrome [11].

Exercise training programs can improve the insulin sensitivity, the vascular endothelium function, the glycemic control, and the blood pressure [12]. However, there have been few studies of changes of cardiovascular parameters with physical exercise programs in the obese children.

In Egypt, no study has examined the relationship between exercise and metabolic syndrome in the children. Therefore, the aims of this work were to:-

- Evaluate the effect of physical training on BMI, lipid profile, CRP, leptin and insulin resistance among obese Egyptian children with and without metabolic syndrome.

- Assess the relationship between HOMA-IR and the metabolic syndrome parameters.

\section{Methods}

\section{Subject selection}

Ninety three children of both sexes, aged from 8 to 12 years old, were included in this study. Three groups comprising:

1 Control normal weight group $(\mathrm{n}=49)$ normal weight children with a BMI value between the $25^{\text {th }}$ and $74^{\text {th }}$ percentile.

2 Obese without metabolic syndrome group $(\mathrm{n}=32)$.

3 Obese with metabolic syndrome group $(n=12)$.

\section{Obese children}

are those with BMI greater than $95^{\text {th }}$ percentile for their age and gender. They were recruited in the nutritional clinic in the University Hospital by open invitation. Both the children and their parents were fully informed of the nature and purpose of the present study, and written informed consents were obtained. The experimental protocols were approved by the Medical Ethics Committee of Minia University and the investigations were conducted according to the principles expressed in the Declaration of Helsinki.

None of the subjects used drugs or therapies for obesity, and none had a past history of disease or injury that would prevent daily exercise. Children were currently participating in an organized physical activity training program over the previous 6 months, and were also excluded from the study.

\section{Diagnosis of metabolic syndrome}

The criteria for the metabolic syndrome in adults developed by the National Cholesterol Education Program were modified and devised by many investigators [13-15]. as a child-specific definition which includes abnormalities in any three of the following factors: fasting glucose level (>110 mg/dL), TG level (>110 mg/dL), HDL-C level $(<40 \mathrm{mg} / \mathrm{dL})$, systolic or diastolic blood pressure $\left(>90^{\text {th }}\right.$ percentile), and BMI $\left(>85^{\text {th }}\right.$ percentile).

\section{Anthropometric measurement}

Body weight and height were measured on the same day to the nearest $0.1 \mathrm{~kg}$ and the nearest $0.1 \mathrm{~cm}$, respectively. The BMI was calculated as the weight in kilograms divided by the square of the height in meters. The waist circumference was measured to the nearest $0.1 \mathrm{~cm}$, using a non-extendable flexible tape applied above the iliac crest and parallel to the ground; with the subject standing erect with abdomen relaxed, arms along the body, and feet together.

\section{Exercise training intervention}

All children performed a set of exercises 3 days a week, for 12 weeks by a trained exercise physiologist. At each training session, they performed warm-up exercises for $5-10 \mathrm{~min}$, followed by a $20-45 \mathrm{~min}$ walking-jogging exercise, with a target heart rate reserve of $60-65 \%$, and relaxation exercises for $5-10 \mathrm{~min}$ at the end of the exercise period.

The heart rate reserve, used to calculate the intensity of exercise, was determined by counting heart beats at the carotid artery $10 \mathrm{~s}$ after the cessation of exercise and then using the Karvonen equation [(heart rate maximum heart rate rest $) \times(0.60-0.65)]+$ heart rate rest $[16]$.

\section{Measurements and biochemistry}

Blood samples were collected, via the cannulated antecubital vein, between 8:00-9:00 a.m. after an overnight fasting for all groups before and after the exercise program. Serum and platelet-poor plasma were obtained by centrifugation at $2000 \mathrm{~g}$ at a temperature of $4^{\circ} \mathrm{C}$ for 15 minutes. The samples were subsequently stored at $-80^{\circ} \mathrm{C}$ until assayed.

TC, TG and HDL-C were measured using an enzymatic colorimetric assay (Human Gesellschaft for Biochemica and Diagnostica). LDL was calculated from the TC, TG and HDL according to the method of Friedewald et al. [17].

$$
\mathbf{L D L}-\mathrm{C}(\mathrm{mg} / \mathbf{d l})=\mathrm{TC}-\mathrm{TG} / \mathbf{5}-\mathrm{HDL}-\mathrm{C} .
$$

Plasma glucose was determined by a glucose oxidase method (Sclavo Diagnostics International SPI). CRP was measured by turbidimetry (biosystems). Plasma leptin 
was measured by the DSL (Webster, TX) $10-23100$ ACTIVE Human Leptin enzyme-linked immunosorbant ELISA, an enzymatically amplified "two step" immunoassay. Plasma insulin was measured by the DSL-101600- ACTIVE insulin enzyme - linked immunosorbant ELISA. Insulin resistance (IR) was calculated by the homoeostasis model assessment (HOMA-IR) index as: [fasting insulin $(\boldsymbol{\mu U} / \mathbf{m l}) \times$ fasting glucose $(\mathbf{m m o l} / \mathbf{L}) /$ 22.5]. To distinguish normal from impaired insulin sensitivity, HOMA-IR greater than 2.5 and 4.0 were the cutoff points used in children and adolescents, respectively [18].

\section{Statistical analysis}

The data were reported as mean $\pm \mathrm{SD}$, and analysed using the SPSS $^{\circledR}$ statistical package, version 11.0 (SPSS Inc., Chicago, IL, USA) for Windows ${ }^{\circledR}$.

We verified normal distribution of variables with a Kolmogorov-Smirnov test, and the parametric variables with skewed distribution were expressed as mean $\pm \mathrm{SD}$. For the nonparametric variables (leptin, CRP, and TG); the median, along with the minimum and maximum values, were expressed in the descriptive tables. The comparisons between the measurements of the parametric parameters were determined by paired and unpaired samples $t$ test.

Statistically significant differences were tested with the nonparametric Kruskal-Wallis test for quantitative items, and with the nonparametric Wilcoxon test for paired observations.

Binary logistic regression analysis was performed to examine the relationship between obesity and metabolic syndrome components.

Pearson's correlation coefficients were used to evaluate the correlations between HOMA-IR and the individual components of the metabolic syndrome. A $P$-value of $<0.05$ was considered to be statistically significant.

\section{Results}

Table 1 shows the clinical and biological characteristics of the study group. The mean age of boys and girls was
Table 1 Clinical and biological characteristics of the studied population according to sex

\begin{tabular}{lcc}
\hline Girls $(\mathbf{n}=\mathbf{4 0})$ & Boys $(\mathbf{n}=\mathbf{5 3})$ & Characteristics \\
\hline $10.05 \pm 1.16$ & $10.5 \pm 1.27$ & Age $(\mathrm{y})$ \\
$55.4 \pm 7.8$ & $57.6 \pm 8.4$ & Weight $(\mathrm{kg})$ \\
$146.3 \pm 8.7$ & $149.4 \pm 8.8$ & Height $(\mathrm{cm})$ \\
$21.4 \pm 6.1$ & $22.7 \pm 6.4$ & BMI $\left(\mathrm{kg} / \mathrm{m}^{2}\right)$ \\
$70.2 \pm 9.5$ & $70.4 \pm 10.6$ & Waist circumference \\
$0.84 \pm 0.05$ & $0.83 \pm 0.06$ & Waist-hip ratio \\
$112.3 \pm 7.7$ & $114.8 \pm 8.9$ & Systolic BP $(\mathrm{mmHg})$ \\
$74.6 \pm 8.04$ & $73.9 \pm 6.9$ & diastolic BP $(\mathrm{mmHg})$ \\
$160 \pm 24.9$ & $161.5 \pm 21.6$ & Total cholesterol $(\mathrm{mg} / \mathrm{dL}))$ \\
$98.4 \pm 15.8$ & $100.3 \pm 13.9$ & LDL $\pm C(\mathrm{mg} / \mathrm{dL})$ \\
$45.8 \pm 8.2$ & $47.1 \pm 8.6$ & HDL-C $(\mathrm{mg} / \mathrm{dL})$ \\
$88(75-135)$ & $95(72-150)$ & Triglyceride $(\mathrm{mg} / \mathrm{dL}) \dagger$ \\
$85.9 \pm 7.3$ & $88.4 \pm 10.9$ & Glucose $(\mathrm{mg} / \mathrm{dL})$ \\
$15.3 \pm 4.6$ & $14.8 \pm 4.9$ & Insulin $(\mathrm{IU} / \mathrm{mL})$ \\
$2.6 \pm 0.8$ & $2.7 \pm 0.8$ & HOMA-IR \\
$0.24(0.01-2.5)$ & $0.9(0.01-2.6)$ & CRP $(\mathrm{mg} / \mathrm{L}) \dagger$ \\
$5.7(0.6-21.5)$ & $6.5(0.6-36.5)$ & Serum leptin $(\mathrm{ng} / \mathrm{mL}) \dagger$ \\
\hline
\end{tabular}

Data marked with † were presented as medians (interquartile ranges) and all others were presented as means \pm standard deviations.

$10.5 \pm 1.27$ years and $10.05 \pm 1.16$ years respectively. The mean weight of boys and girls was $57.6 \pm 8.4$ and $55.4 \pm 7.8$ respectively.

The distribution of five risk factors of the metabolic syndrome and the full syndrome with its odds ratio among the children are shown in Table 2. Low HDL-C was present in $34.1 \%$ of the obese vs. $4.1 \%$ of the normal-weight children $(\mathrm{p}<0.001)$. Similarly for TG $(25 \%$ vs. $8.2 \%)(\mathrm{p}<0.01)$ and high systolic blood pressure $(27.3 \%$ vs. $10.2 \%)(\mathrm{p}<0.05)$. Metabolic syndrome was diagnosed in $27.3 \%$ of the obese children and none of the normal-weight children. Among the risk factors, low HDL-C gave the highest odds of 1.2 (95\% CI 1.02, 1.3) of developing metabolic syndrome followed by high

Table 2 Metabolic profile and metabolic syndrome components among the studied children according to sex

\begin{tabular}{|c|c|c|c|c|c|c|c|}
\hline \multirow[t]{2}{*}{ Characteristic } & \multicolumn{3}{|c|}{ Obese children } & \multicolumn{3}{|c|}{ Control } & \multirow[t]{2}{*}{ OR $(95 \% \mathrm{Cl})^{\mathrm{a}}$} \\
\hline & $\begin{array}{c}\text { Females } \\
(n=16) \\
n(\%)\end{array}$ & $\begin{array}{c}\text { Males } \\
(n=28) \\
n(\%)\end{array}$ & $\begin{array}{c}\text { Total } \\
(n=44) \\
n(\%)\end{array}$ & $\begin{array}{c}\text { Females } \\
(n=24) \\
n(\%)\end{array}$ & $\begin{array}{c}\text { Males } \\
(n=25) \\
n(\%)\end{array}$ & $\begin{array}{c}\text { Total } \\
(n=49) \\
n(\%)\end{array}$ & \\
\hline $\mathrm{BMI}>85$ th percentile & $16(100)$ & $28(100)$ & $44(100)$ & $0(0)$ & $0(0)$ & $0(0)$ & - \\
\hline Impairment of glucose tolerance & $3(18.7)$ & $4(14.3)$ & $7(15.9)$ & $2(8.3)$ & $1(4)$ & $3(6.1)$ & $0.9(0.86-1.04)$ \\
\hline Systolic blood Pressure $>$ 95th Percentile & $5(31.2)$ & $7(25)$ & $12(27.3)$ & $2(8.3)$ & $3(12)$ & $5(10.2)$ & $0.8(0.7-0.9)^{b}$ \\
\hline $\mathrm{HDL}<5$ th percentile & $6(37.5)$ & $9(32.1)$ & $15(34.1)$ & $2(8.2)$ & $0(0)$ & $2(4.1)$ & $1.2(1.02-1.3)^{d}$ \\
\hline Triglycerides $>95$ th percentile & $3(18.7)$ & $8(28.6)$ & $11(25)$ & $1(4.2)$ & $3(12)$ & $4(8.2)$ & $0.9(0.8-0.9)^{c}$ \\
\hline Metabolic syndrome & $4(25)$ & $8(28.6)$ & $12(27.3)$ & $0(0)$ & $0(0)$ & (0) & - \\
\hline
\end{tabular}

b significant at $p<0.05 ; c$ significant at $p<0.01$; $d$ significant at $p<0.001$

a OR calculated from logistic regression test by using enter method. 
Table 3 Clinical and biological characteristics of the studied population with weight and metabolic syndrome status specification

\begin{tabular}{|c|c|c|c|}
\hline & $\begin{array}{l}\text { Control children }(n=49) \\
\text { Mean } \pm \text { SD }\end{array}$ & $\begin{array}{l}\text { Obese children without metabolic } \\
\text { syndrome }(n=32) \text { Mean } \pm \text { SD }\end{array}$ & $\begin{array}{l}\text { Obese childrenwith metabolic } \\
\text { syndrome }(n=12) \text { Mean } \pm S D\end{array}$ \\
\hline Age $(y)$ & $10.1 \pm 1.21$ & $10.2 \pm 1.2$ & $11.04 \pm 1.15^{\mathrm{a}, \mathrm{b}}$ \\
\hline Weight (kg) & $62.6 \pm 4.1^{C}$ & $50.2 \pm 3.7$ & $67.1 \pm 6.3^{a, b}$ \\
\hline Height $(\mathrm{cm})$ & $146.5 \pm 10.3$ & $147.6 \pm 7.5$ & $153.9 \pm 8.5^{\mathrm{a}, \mathrm{b}}$ \\
\hline $\mathrm{BMI}\left(\mathrm{kg} / \mathrm{m}^{2}\right)$ & $27.01 \pm 3.9^{C}$ & $17.2 \pm 2.5$ & $29.4 \pm 4.8^{a, b}$ \\
\hline Waist circumference & $77.3 \pm 5.2^{C}$ & $62.7 \pm 6.6$ & $83.25 \pm 2.8^{\mathrm{a}, \mathrm{b}}$ \\
\hline Waist-hip ratio & $0.85 \pm 0.06$ & $0.83 \pm 0.06$ & $0.88 \pm 0.05^{b}$ \\
\hline Systolic BP (mmHg) & $117.5 \pm 6.8^{c}$ & $109.4 \pm 6.9$ & $121.7 \pm 7.8^{b}$ \\
\hline diastolic BP (mmHg) & $75.5 \pm 8.3^{c}$ & $71.8 \pm 6.3$ & $80.4 \pm 4.5^{a} \mathrm{~b}$ \\
\hline $\begin{array}{l}\text { Total cholesterol } \\
(\mathrm{mg} / \mathrm{dL}))\end{array}$ & $178.5 \pm 16.8^{c}$ & $145.2 \pm 13.6$ & $177.7 \pm 21.9^{b}$ \\
\hline $\mathrm{LDL} \pm C(\mathrm{mg} / \mathrm{dL})$ & $107 \pm 10.2^{C}$ & $92.6 \pm 14.5$ & $107.5 \pm 12.1^{b}$ \\
\hline $\mathrm{HDL}-\mathrm{C}(\mathrm{mg} / \mathrm{dL})$ & $45.8 \pm 5.9^{C}$ & $50.5 \pm 6.5$ & $32 \pm 2.7^{\mathrm{a}, \mathrm{b}}$ \\
\hline $\begin{array}{l}\text { Triglyceride } \\
(\mathrm{mg} / \mathrm{dL})\end{array}$ & $95.5(76-135)^{c}$ & $85(72-123)$ & $118.5(110-150)^{a, b}$ \\
\hline Glucose (mg/dL) & $84.9 \pm 5.7$ & $84.1 \pm 5.2$ & $105.5 \pm 11.04^{a, b}$ \\
\hline Insulin ( IU/mL) & $14.4 \pm 3.9$ & $14.4 \pm 4.9$ & $19.3 \pm 4.4^{a, b}$ \\
\hline HOMA-IR & $2.7 \pm 0.9$ & $2.4 \pm 0.6$ & $3.3 \pm 0.88^{a, b}$ \\
\hline CRP $(\mathrm{mg} / \mathrm{L})$ & $1.25(0.01-2.6)^{C}$ & $0.2(0.01-1.5)$ & $2.1(1.2-3.1)^{a, b}$ \\
\hline Serum leptin $(\mathrm{ng} / \mathrm{mL})$ & $9.4(0.6-36.5)^{c}$ & $4.5(0.6-12.4)$ & $15.2(8.3-21.8)^{a, b}$ \\
\hline
\end{tabular}

$\mathrm{a}=$ significant difference between obese children with and without metabolic syndrome.

$b=$ significant difference between non obese children and obese children with metabolic syndrome.

$\mathrm{c}=$ significant difference between non obese children and obese children without metabolic syndrome.

fasting blood glucose $(\mathrm{OR}=0.9 ; 95 \% \mathrm{CI} 0.86,1.04)$, and high triglycerides $(\mathrm{OR}=0.9 ; 95 \%$ CI $0.8,0.9)$.

Children with metabolic syndrome had a significantly higher body weight, BMI and waist circumference compared to obese and control groups (Table 3). Serum insulin, glucose, diastolic blood pressure, TG, leptin and CRP were significantly higher in metabolic syndrome group compared to obese and control groups. TC, LDL-C and systolic blood pressure values were significantly higher in metabolic syndrome group, compared to control group. The body weight, BMI, waist circumference, systolic and diastolic blood pressure, as well as TC, LDL-C, TG, leptin, and CRP levels were significantly higher in the obese group without metabolic syndrome than in the control group (Table 3 ).

There were significant correlations between HOMA-IR and the individual components of the metabolic syndrome (Table 4).

Table 5 shows that obese participants with metabolic syndrome showed significant reductions in weight, BMI, waist circumference, TG, glucose, insulin and CRP, and an increase in HDL-C after 12 weeks of training. The obese participants without metabolic syndrome presented significant reductions in weight, BMI, TC, LDL-C, CRP and leptin, and an increase in $\mathrm{HDL}-\mathrm{C}$ in response to training.
The analysis of changes in parameters of metabolic syndrome is summarized in Figure 1. The percentage of metabolic syndrome decreased from $12.9 \%$ before the exercise training to $7.5 \%$ after training. Also, there was a significant reduction in BMI (from 47.3 to $32.6 \%$ ), systolic blood pressure (from 18.3 to $15.1 \%$ ), and in HDL-C (from 18.3 to $9.7 \%$ ).

\section{Discussion}

Metabolic syndrome was diagnosed in 12 (27.3\%) of the total number of obese children, most of them correspond to the male group. It is slightly lower than a

Table 4 Pearson Correlation Coefficients between HOMA-IR and the individual components of the metabolic syndrome

\begin{tabular}{lcl}
\hline Variables & $\mathbf{r}$ & $\mathbf{p}$ \\
\hline Triglycerides* & 0.41 & 0.001 \\
HDL-C & -0.20 & 0.05 \\
Systolic blood pressure & 0.28 & 0.005 \\
BMI $>85^{\text {th }}$ percentile & 0.22 & 0.03 \\
Fasting glucose & 0.29 & 0.004 \\
\hline
\end{tabular}

$\mathrm{HDL}-\mathrm{C}=$ high-density lipoprotein cholesterol; HOMA-IR = insulin resistance as assessed by homeostasis model. *Spearman rho correlation. 
Table 5 Changes in clinical and biological characteristics among the studied groups undergoing 12 week exercise program

\begin{tabular}{|c|c|c|c|c|c|c|}
\hline & \multicolumn{2}{|c|}{$\begin{array}{l}\text { Normal weight }(n=49) \\
\text { Mean } \pm \text { SD }\end{array}$} & \multicolumn{2}{|c|}{$\begin{array}{l}\text { Obese with out metabolic syndrome } \\
(n=32) \text { Mean } \pm \text { SD }\end{array}$} & \multicolumn{2}{|c|}{$\begin{array}{l}\text { Obese with metabolic syndrome } \\
(n=12) \text { Mean } \pm \text { SD }\end{array}$} \\
\hline & Baseline & Post-interventional & Baseline & Post-interventional & Baseline & Post-interventional \\
\hline Weight (kg) & $50.2 \pm 3.7$ & $49.6 \pm 3.7$ & $62.6 \pm 4.1$ & $60.2 \pm 4.3^{*}$ & $67.1 \pm 6.3$ & $60.9 \pm 2.8^{*}$ \\
\hline BMI $\left(\mathrm{kg} / \mathrm{m}^{2}\right)$ & $17.2 \pm 2.5$ & $16.8 \pm 2.8$ & $27.01 \pm 3.9$ & $24.8 \pm 3.1^{*}$ & $29.4 \pm 4.8$ & $24.2 \pm 2.2^{*}$ \\
\hline Waist circumference & $62.7 \pm 6.6$ & $61.6 \pm 5.9$ & $77.3 \pm 5.2$ & $76.2 \pm 5.6$ & $83.25 \pm 2.8$ & $77.6 \pm 5.2^{*}$ \\
\hline Waist-hip ratio & $0.83 \pm 0.06$ & $0.80 \pm 0.08$ & $0.85 \pm 0.06$ & $0.83 \pm 0.06$ & $0.88 \pm 0.05$ & $0.85 \pm 0.06$ \\
\hline Systolic BP (mmHg) & $109.4 \pm 6.9$ & $109.7 \pm 7.1$ & $117.5 \pm 6.8$ & $116.4 \pm 7.2$ & $121.7 \pm 7.8$ & $117.5 \pm 6.9$ \\
\hline diastolic BP (mmHg) & $71.8 \pm 6.3$ & $71.6 \pm 5.8$ & $75.5 \pm 8.3$ & $72.2 \pm 8.2$ & $80.4 \pm 4.5$ & $77.1 \pm 8.9$ \\
\hline Total cholesterol (mg/dL)) & $145.2 \pm 13.6$ & $139.3 \pm 15.1$ & $178.5 \pm 16.8$ & $154.8 \pm 20.7^{*}$ & $177.7 \pm 21.9$ & $166.3 \pm 9.9$ \\
\hline $\mathrm{LDL} \pm C(\mathrm{mg} / \mathrm{dL})$ & $92.6 \pm 14.5$ & $91.7 \pm 14.9$ & $107 \pm 10.2$ & $99.4 \pm 15.4^{*}$ & $107.5 \pm 12.1$ & $103.8 \pm 15.7$ \\
\hline $\mathrm{HDL}-\mathrm{C}(\mathrm{mg} / \mathrm{dL})$ & $50.5 \pm 6.5$ & $51.9 \pm 5.4$ & $45.8 \pm 5.9$ & $49.3 \pm 6.5^{*}$ & $32 \pm 2.7$ & $43.4 \pm 6.2^{*}$ \\
\hline Triglyceride (mg/dL) & $85(72-123)$ & $85(72-112)$ & $95.5(76-135)$ & $95.4(76-124)$ & $118.5(110-150)$ & $103.5(89-135)^{*}$ \\
\hline Glucose (mg/dL) & $84.1 \pm 5.2$ & $83.3 \pm 5.6$ & $84.9 \pm 5.7$ & $84.6 \pm 5.5$ & $105.5 \pm 11.04$ & $91.7 \pm 10.8^{*}$ \\
\hline Insulin ( IU/mL) & $14.4 \pm 4.9$ & $13.9 \pm 4.9$ & $14.4 \pm 3.9$ & $14.2 \pm 4.6$ & $19.3 \pm 4.4$ & $13.6 \pm 4.01^{*}$ \\
\hline HOMA-IR & $2.4 \pm 0.6$ & $2.4 \pm 0.5$ & $2.7 \pm 0.9$ & $2.5 \pm 0.7$ & $3.3 \pm 0.88$ & $2.7 \pm 0.9$ \\
\hline CRP (mg/L) & $0.2(0.01-1.5)$ & $0.2(0.01-1.5)$ & $1.25(0.01-2.6)$ & $0.22(0.01-2.1)^{*}$ & $2.1(1.2-3.1)$ & $1.2(0.04-2.25)^{*}$ \\
\hline Serum leptin (ng/mL) & $4.5(0.6-12.4)$ & $3.8(0.6-7.5)$ & $9.4(0.6-36.5)$ & $5.7(0.6-16.9)^{*}$ & $15.2(8.3-21.8)$ & $6.1(0.6-21.5)$ \\
\hline
\end{tabular}

${ }^{*} P<0.05$ for baseline vs after 12 weeks of physical exercise program within each group.

previous study [19]. which reported that metabolic syndrome with obesity occurs in $38.7 \%$ of moderately obese and $49.7 \%$ of severely obese children and adolescents.

The relationship between obesity and CRP levels in the children is limited, especially among the children younger than 12 years of age [20]. In the present study, CRP concentrations were elevated predominantly in obese individuals who were also insulin resistant and fall in parallel with weight loss-associated improvements in IR. CRP levels increased significantly in the group of obese children with or without metabolic syndrome compared to control group. Obese with metabolic syndrome group had higher CRP and insulin level in comparison with obese without metabolic syndrome group. This finding was in agreement with a previous study [21]. which found positive significant correlation between CRP, BMI, insulin level

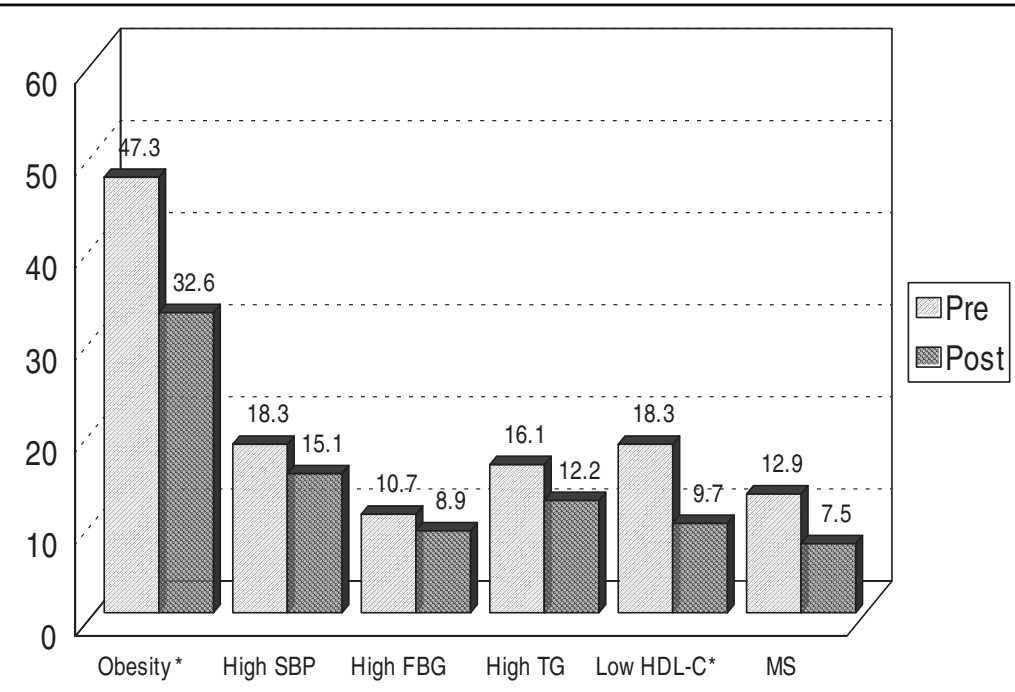

Figure 1 Variables in metabolic syndrome components before and after exercise intervention in all exercisers $(n=93)$. 
and IR. The mechanisms responsible for the association between CRP, BMI and IR are not yet clearly understood. It is possible that with increasing BMI, adipose tissue is a direct source of pro-inflammatory cytokines such as tumour necrosis factor-alpha (TNF- $\alpha$ ) which, in turn, act as stimuli for CRP synthesis in the liver [22]. This leads to a chronic inflammatory state and contributes to IR [23].

In the present study the metabolic syndrome group had a greater TG and a lower HDL-C concentration similar to previous reports [24,25]. There were significant correlations between HOMA-IR and the individual components of the metabolic syndrome, including TG. IR is associated with decreased lipoprotein lipase activity, resulting in decreased clearance of TG, as well as increased lipolysis in adipose tissue and increased synthesis of very-low-density lipoprotein particles in the liver [26]. We found that exercise decreased TG and increased HDL-C by reversal of this effect.

Several physiological mechanisms exist to explain the changes in CRP and IR with exercise. Improvements in IR have been observed in adults upon participation in exercise programs; however, similar studies in overweight and obese children are limited [27,28]. Exercise is known to increase insulin-receptor autophosphorylation, glucose transporter 4 expressions and glucose transport [29]. Exercise increases the uptake of glucose by muscle cells which, consequently, increases the oxidation of glucose which leads to improvement in IR [30]. Exercise decreased CRP as reported in studies in adults reported by [31]. Exercise training reduces CRP both directly by reducing cytokine production in fat, muscle, and mononuclear cells, and indirectly by increasing insulin sensitivity, improving endothelial function, and reducing body weight [32].

The most significant effects of exercise on metabolic syndrome parameters are observed in HDL-C. This is in agreement with a previous study [33] which reported that the effects of exercise on HDL-C levels are most clearly seen in overweight persons with high TG levels and low HDL-C levels at baseline. In contrast, lean subjects with isolated low HDL-C levels had no significant increase in HDL-C with exercise, even though their lipoprotein lipase activity was increased. This suggests that the changes in HDL-C and LDL-C may be secondary to improvements in hypertriglyceridemia, IR, and adiposity. Other mechanisms for changes in HDL-C include increases in lipoprotein lipase activity and decreases in hepatic lipase and cholesteryl ester transfer protein $[34,35]$.

Previous studies confirmed a positive relation between increased BMI and leptin levels in children and adolescents [36-38]. The results obtained in the present study demonstrated that leptin decreased significantly with exercise in obese without metabolic syndrome group, and this is in agreement with another study [39].
Obese children are associated with arterial endothelial dysfunction, which elevated blood pressure [40]. Exercise decreased both systolic and diastolic blood pressures. Potential mechanisms responsible for this change may include increased endothelial nitric oxide synthase activity and increased insulin sensitivity [41].

The present study had limitations, including that this project focused on increasing physical activity and no dietary intervention or outcomes were measured. Another limitation of the current study was the measurements of others inflammatory markers, such as TNF-alpha and IL-6, which would further increase the validity of the results, were not assessed due to high cost.

\section{Conclusions}

Obese children exhibit several risk factors for the development of cardiovascular diseases and that metabolic syndrome is already a reality for many children, being present in $27.3 \%$ of the obese children investigated here. Exercise intervention reduces CRP, may be effective in preventing the occurrence of cardiovascular events. Regular physical activity is one of the most important non pharmacologic tools in reducing the overall cardiometabolic risk via regulating the body weight, BP and the lipid profile. Further studies will be required to assess the responses related to the degree of obesity, as well as the intensity and the duration of intervention.

\section{Abbbreviations}

MS: Metabolic syndrome; CRP: C-reactive protein; TG: Triglycerides; HDLC: High-density lipoprotein cholesterol; TC: Total cholesterol; LDL-C: Lowdensity lipoprotein cholesterol; HOMA-IR: Homeostatic model assessment insulin resistance.; TNF-alpha: Tumor necrosis factor alpha; BMI: Body mass index.

\section{Competing interests}

No conflict of interest has been declared.

\section{Authors' contributions}

Author's contribution to the paper is about equal. NNK collected data from the children, participated in the concept and design of the study, made the statistical analysis and wrote the manuscript. MMR designed and performed some biochemical kits measurements, contributed to the discussion and wrote the manuscript. All authors read and approved the final manuscript.

\section{Acknowledgements}

We would like to acknowledge the all children and their parents who participated in the study for their help and support. Great thanks to $\mathrm{Mr}$. Sameh Eshak (sport trainer and teacher of physical education).

\section{Author details}

${ }^{1}$ Lecturer of public health, Public health department, Faculty of Medicine, Minia University, Minia, Egypt. ${ }^{2}$ Lecturer of physiology, Physiology

department, Faculty of Medicine, Minia University, Minia, Egypt.

Received: 15 November 2011 Accepted: 6 March 2012

Published: 12 June 2012

\section{References}

1. Alberti KG, Zimmet P, Shaw J: The metabolic syndrome-a new worldwide definition. Lancet 2005, 366(9491):1059-1062. 
2. Singh R, Bhansali A, Sialy R, Aggarwal A: Prevalence of metabolic syndrome in adolescents from a north Indian population. Diabet Med 2007, 24(2):195-199

3. Fu J-F, Liang L, Zou C-C, Hong F, Wang C-L, Wang X-M: Prevalence of the metabolic syndrome in Zhejiang Chinese obese children and adolescents and the effect of metformine combined with lifestyle intervention. Int J Obes 2007, 31:15-22.

4. Yoshinaga M, Tanaka S, Shimago A, Sameshima K, Nishi J, Nomura Y, Kawano Y, Hashiguchi J, Ichiki T, Shimizu S: Metabolic syndrome in overweight and obese Japanese children. Obes Res 2005, 0(7):1135-1140. 0(4): 627-633

5. Zimmet $P$, Alberti $G$, Kaufman F: The metabolic syndrome in children and adolescents. Lancet 2007, 369:2059-2061.

6. Ford E: Prevalence of the metabolic syndrome defined by the International Diabetes Federation among adults in the U.S. Diabetes Care 2005, 28(11):2745-2749.

7. Pearson TA, Mensah GA, Alexander RW, Anderson JL, Cannon RO III, Criqui M, Fadl YY, Fortmann SP, Hong Y, Myers GL, Rifai N, Smith SC, Taubert K, Tracy RP, Vinicor F: Markers of inflammation and cardiovascular disease: application to clinical and public health practice: a statement for healthcare professionals from the Centers for Disease Control and Prevention and the American Heart Association. Circulation 2003, 107:499-511.

8. Ridker PM, Rifai N, Rose L, Buring JE, Cook NR: Comparison of C-reactive protein and low-density lipoprotein cholesterol levels in the prediction of first cardiovascular events. N Engl J Med 2002, 347:1557-1565.

9. Juonala M, Viikari J, Ronnemaa T, Taittonen L, Marniemi J: Childhood C-reactive protein in predicting CRP and carotid intima thickness in adulthood: the Cardiovascular Risk in Young Finns Study. Arterioscler. Thromb. Vasc Biol 2006, 26:1883-1888.

10. Webber J: Energy balance in obesity. Proc Nutr Soc 2003, 62:539-543.

11. Moran O, Phillip M: Leptin: obesity, diabetes and other peripheral effects-a review. Pediatric Diabetes. 2003, 4(2):101-109.

12. Barness LA: Obesity in children. Fetal Pediatr. Pathol. 2007, 26:75-85.

13. Lambert M, Paradis G, O'Loughlin J, Delvin EE, Hanley JA, Levy E: Insulin resistance syndrome in a representative sample of children and adolescents from Quebec, Canada. Int J Obes Relat Metab Disord 2004, 28:833-841.

14. De Ferranti SD, Gauvreau K, Ludwig DS, Neufeld EJ, Newburger JW, Rifai N: Prevalence of the metabolic syndrome in American adolescents: findings from the Third National Health and Nutrition Examination Survey. Circulation 2004, 110:2494-2497.

15. Cook S, Weitzman M, Auinger P, Nguyen M, Dietz WH: Prevalence of a metabolic syndrome phenotype in adolescents: findings from the third National Health and Nutrition Examination Survey, 1988-1994. Arch. Pediatr. Adolesc. Med. 2003, 157:821-827.

16. Karacabey K, Saygin O, Ozmerdivenli R, Simsek E, Bulut S, Karacabey K Saygin $O$ : The effects of exercise on the immune system and stress hormones in sportswomen. Neuro Endocrinol. Lett. 2005, 26:361-366.

17. Friedewald WT, Levy RI, Fredrickson DS: Estimation of the concentration of low-density lipoprotein cholesterol in plasma, without use of the preparative ultracentrifuge clin. Chem. 1972, 18:499-502.

18. d'Annunzio G, Vanelli M, Meschi F, Pistorio A, Caso M, Pongiglione C: The SIEDP Study Group Valori normali di HOMA-IR in bambinie adolescenti: studio multicentrico italiano Quad. Pediatr 2004, 3:44.

19. Steinberger J, Daniels SR, Eckel RH, Hayman L, Lustig RH: Progress and challenges in metabolic syndrome in children and adolescents: a scientific statement from the American Heart Association Atherosclerosis, Hypertension, and Obesity in the Young Committee of the Council on Cardiovascular Disease in the Young; Council on Cardiovascular Nursing; and Council on Nutrition, Physical Activity, and Metabolism. Circulation 2009, 119:628-647.

20. Hiura M, Kikuchi T, Nagasaki K, Uchiyama M: Elevation of serum C- reactive protein levels is associated with obesity in boys. Hypertens Res 2003 26(7):541-546.

21. Thomas NE, Baker JS, Graham MR, Cooper SM, Davies B: C-reactive protein in schoolchildren and its relation to adiposity, physical activity, aerobic fitness and habitual diet. Br. J. Sports Med. 2008, 42(5):357-360.

22. Warnberg J, Nova E, Romeo J, Moreno LA, Sjostrom M, Marcos A: Lifestyle-related determinants of inflammation in adolescence. $\mathrm{Br}$ J Nutr 2007, 98(1):S116-S120.
23. Weisberg SP, McCann D, Desai M, Rosenbaum M, Leibel RL, Ferrante AW: Obesity is associated with macrophage accumulation in adipose tissue. J Clin Invest 2003, 112:1796-1808.

24. Cruz ML, Weigensberg MJ, Huang TTK, Ball G, Shaibi GQ, Goran MI: The metabolic syndrome in overweight Hispanic youth and the role of insulin sensitivity. J Clin Endocrinol Metab 2004, 89:108-113.

25. Weiss F, Dziura J, Burgert T, Tamborlane WW, Taksali SE, Yeckel CW: Obesity and the metabolic syndrome in children and adolescents. $N$ Engl J Med 2004, 350:2362-2374

26. Nassis GP, Papantakou K, Skenderi K, Triandafillopoulou M, Kavouras SA, Yannakoulia M: Aerobic exercise training improves insulin sensitivity without changes in BW, body fat, adiponectin, and inflammatory markers in overweight and obese girls. Metabolism 2005, 54:1472-1479.

27. Park TG, Hong HR, Lee J, Kang HS: Lifestyle plus exercise intervention improves metabolic syndrome markers without change in adiponectin in obese girls. Ann Nutr Metab 2007, 51:197-203.

28. Youngren JF, Keen S, Kulp JL, Tanner CJ, Houmard JA, Goldfine ID: Enhanced muscle insulin receptor autophosphorylation with short-term aerobic exercise training. Am J Physiol Endocrinol Metab 2001, 280:528-533.

29. Goran MI, Bergman RN, Avila Q, Watkins M, Ball GD, Shaibi GQ, Weigensberg MJ, Cruz ML: Impaired glucose tolerance and reduced beta-cell function in overweight Latino children with a positive family history for type 2 diabetes. J Clin Endocrinol Metab 2004, 89:207-212.

30. Jensen J, Lai YC: Regulation of muscle glycogen synthase phosphorylation and kinetic properties by insulin, exercise, adrenaline and role in insulin resistance. Arch Physiol Biochem 2009, 115:13-21.

31. Esposito K, Pontillo A, Di Palo C, Giugliano G, Masella M, Marfella R, Giugliano D: Effect of weight loss and lifestyle changes on vascular inflammatory markers in obese women: a randomized trial. JAMA. 2003, 289:1799-1804

32. Kasapis C, Thompson P: The effects of physical activity on serum Creactive protein and inflammatory markers: a systematic review. J Am Coll Cardiol 2005, 45(10):1563-1569.

33. Couillard C, Despres JP, Lamarche B, Bergeron J, Gagnon J, Leon AS: Effects of endurance exercisetraining on plasma HDL cholesterol levels depend on levels of triglycerides: evidence from men of the Health, Risk Factors, Exercise Training and Genetics (HERITAGE) Family Study. Arterioscler Thromb Vasc Biol 2001, 21:1226-1232.

34. Jiang XC, Moulin P, Quinet E, Goldberg IJ, Yacoub LK, Agellon LB, Compton $D$, Schitzer-Polokoff R, Tall AR: Mammalian adipose tissue and muscle are major sources of lipid transfer protein mRNA. J Biol Chem 1991, 266:4631-4639.

35. Tall A: Exercise to reduce cardiovascular risk: how much is enough? N. Eng. J. Med. 2002, 347:1522-1523.

36. Aroonparkmongkol S, Wacharasindhu S, Srivuthana S: Serum levels of leptin in obese Thai children. Chula Med. J. 2005, 49:693-699.

37. Chaichanwatanakul K, Weerakulwattana P, Nunloi S: Leptin level in Thai children and adolescents: relation to body mass index and sexes. Siriraj Med. J 2006, 58(1):006-008

38. Nishimura R, Sano H, Matsudaira T, Myashita Y, Morimoto A, Shirasawa T, Takahashi E, Kawaquchi T, Tajima N: Childhood obesity and its relation to serum adiponectin and leptin: A report from a population-based study. Diabetes Res Clin. Pract. 2007, 76:245-250.

39. Unal M, Unal DO, Baltaci AK, Mogulkoc R, Kayserilioglu A: Investigation of serum leptin levels in professional male football players and healthy sedentary males. Neuro Endocrinology Letters 2005, 26:148-151.

40. Woo KS, Chook P, Yu CW, Sung RY, Qiao M, Leung SS, Lam CW, Metreweli $C$ : Overweight in children is associated with arterial endothelial dysfunction and intima-media thickening. Int. J. Obes. Relat. Metab. Disord. 2004, 28:852-857.

41. Roberts CK, Vaziri ND, Barnard RJ: Effect of diet and exercise intervention on blood pressure, insulin, oxidative stress, and nitric oxide availability. Circulation 2002, 106:2530-2532.

doi:10.1186/1758-5996-4-27

Cite this article as: Kamal and Ragy: The effects of exercise on C-reactive protein, insulin, leptin and some cardiometabolic risk factors in Egyptian children with or without metabolic syndrome. Diabetology \& Metabolic Syndrome 2012 4:27. 